\title{
LIFE HISTORY OF THE COMMON PANDORA, Pagellus erythrinus (LINNAEUS, 1758) (ACTINOPTERYGII: SPARIDAE) FROM SOUTHERN PORTUGAL
}

\author{
Rui Coelho ${ }^{1,2, *}$, Luis Bentes ${ }^{l}$, Carla Correial ${ }^{l}$, Jorge M.S. Gonçalves ${ }^{l}$, Pedro G. Lino ${ }^{3}$, Pedro Monteiro ${ }^{l}$, \\ Joaquim Ribeiro ${ }^{l}$ and Karim Erzini ${ }^{l}$
}

${ }^{1}$ University of Algarve - Centre of Marine Sciences (Campus de Gambelas, 8005-139 Faro, Portugal)

${ }^{2}$ University of Florida - Dickinson Hall - Florida Program for Shark Research, Florida Museum of Natural History (Museum Road, PO Box 117800, Gainesville, FL 32611, US)

${ }^{3}$ Instituto Nacional de Recursos Biológicos, I.P. / IPIMAR

(Av. 5 Outubro s/n, 8700-305 Olhão, Portugal)

* Corresponding author: rpcoelho@ualg.pt

\begin{abstract}
A B S T R A C T
The common pandora, Pagellus erythrinus, is a commercially important seabream for coastal fisheries in the north and central eastern Atlantic. Age, growth and reproductive aspects of the southern Portuguese population were estimated by analysing 386 specimens ranging in total length (TL) from 12.0 to $44.8 \mathrm{~cm}$. Ages were estimated by counting growth bands on otoliths and verified by marginal increment analysis, with specimens ranging in age from 1 to 21 years. The von Bertalanffy growth function was selected as the most adequate model to fit this species' growth, with the estimated parameters being $L_{\text {inf }}=47.14 \mathrm{~cm} \mathrm{TL}, k=0.084$ year $^{-1}$ and $t_{0}=-4.42$ year. The gonads were analyzed macroscopically over a one-year period and the reproductive spawning season found to occur from March to July. The length at first maturity for males occurs at $17.58 \mathrm{~cm}$ TL and 1.15 years while females mature at slightly smaller sizes $(17.29 \mathrm{~cm} \mathrm{TL})$ and younger ages $(1.04$ years). The results presented in this study are important for comparing this population's parameters with those of other populations of the same species occurring in other areas, as well as for future studies, for assessing eventual changes in population parameters over time.
\end{abstract}

\section{RESUMO}

A bica, Pagellus erythrinus, é uma espécie comercialmente importante para as pescarias costeiras do norte e centro este Attântico. A idade, crescimento e aspectos reprodutivos da população que ocorre no sul de Portugal foram estudados através da análise de 386 exemplares com comprimentos totais (TL) entre 12.0 e $44.8 \mathrm{~cm}$. A idade foi estimada pela contagem de bandas de crescimento nos otólitos e verificada pela análise do incremento marginal, tendo-se observado exemplares entre os 1 e 21 anos. A curva de crescimento de von Bertalanffy foi o modelo mais adequado para explicar o crescimento desta espécie, tendo estimado $L_{i n f}=47.14 \mathrm{~cm} \mathrm{TL}, k=0.084 \mathrm{ano}^{-1} \mathrm{e} t_{0}=-4.42$ ano. As gónadas foram analisadas macroscopicamente ao longo do período de um ano e determinou-se que a desova ocorre entre Março e Julho. A primeira maturação dos machos ocorre aos $17.58 \mathrm{~cm}$ TL e 1.15 anos enquanto as fêmeas maturam com tamanhos (17.29 cm TL) e idades (1.04 anos) ligeiramente menores. Os resultados apresentados são importantes para a comparação desta população com populações de outras regiões, assim como para a comparação com estudos futuros, para a determinação de eventuais alterações nos parâmetros populacionais ao longo do tempo.

Descriptors: Age and growth, Fisheries management, Life history, NE Atlantic, Population dynamics, Reproduction, Sparidae.

Descritores: Idade e crescimento, Gestão pesqueira, Ciclo de vida, NE Atlântico, Dinâmica populacional, Reprodução, Sparidae.

\section{INTRODUCTION}

The common pandora, Pagellus erythrinus (Linnaeus, 1758), is a seabream (family Sparidae) that occurs in waters of the continental shelf of the northeastern and central-eastern Atlantic Ocean, from
Norway (Bauchot and Hureau, 1986) to Guinea-Bissau (Sanches, 1991), including the Mediterranean Sea (Bauchot, 1987), and the Madeira, Canary and Cape Verde Islands (Reiner, 1996).

Sea bream species in general play an important role in the continental shelf demersal fish community 
of this region (Gomes et al., 2001). The common pandora is a particularly prized and valuable species among the sea breams, and represents an important resource for southern Portuguese coastal fisheries. In this region, this species is caught mainly by seiners and by an artisanal multi-purpose fishing fleet that operates mainly with trammel nets, gill nets and longlines (Erzini et al., 1998; Stergiou et al., 2006). Even though at present this species is not a major aquaculture resource, it may be considered in the near future as an alternative to other species (Klaoudatos et al., 2004).

Worldwide production of common pandora peaked during 1963-1968, with catches of around $15000 \mathrm{t}$ /year. A second peak was reached during 19811985, with catches above $10000 \mathrm{t} / \mathrm{year}$, but since then a huge decease has been recorded, with catches over the last 20 years (from 1987 to 2007) averaging 4500 t/year. In the Algarve region, the commercial landings of common pandora have also registered significant decreases. While landings in the late 1980's and early 1990's where around 200 t/year (with a peak in 1990 with catches reaching $270 \mathrm{t}$ ), more recent catches have declined with landings always lower than 100 t/year since 2003 (DGPA, 2006).

Several previous studies have focused on estimating population parameters of the common pandora, including age, growth, reproductive aspects and feeding, but these studies have been carried out in the Mediterranean (Ardizzone and Messina, 1983; Andaloro and Giarritta, 1985; Girardin and Quignard, 1985; Papaconstantinou et al., 1988; Livadas, 1989; Mytilineou, 1989; Somarakis and Machias, 2002) and the Canary Islands (Pajuelo and Lorenzo, 1998). This species has been described as showing protogynous hermaphroditism, whereby some larger fish change sex from female to male (Buxton and Garratt, 1990). For the Portuguese coast, Abecasis et al. (2008) has compared ages estimated from scales and otoliths, Gonçalves et al. (1997) has estimated weight-length relationships and Santos et al. (2005) has studied aspects of the species' biology and selectivity. However, no study has ever estimated complete population parameters for the southern Portuguese population integrating aspects of age, growth and reproduction.

The objectives of the present study were to estimate population parameters, including age, growth, maturity and spawning season of the common pandora in southern Portuguese waters. Given the commercial importance of this species for coastal fisheries of the north-eastern and central-eastern Atlantic, the worrying declines in commercial landings over the last decades and the lack of information for the Algarve region in particular, this study represents an important addition for the understanding, management and conservation of the common pandora.

\section{MATERIALS AND MethodS}

Study Area and Data Collection

The specimens sampled and used for this study came from several different research projects carried out by the authors over recent years (between 1995 and 2000) in the southern Portuguese region (Erzini et al., 1996; Erzini et al., 1998; Erzini et al., 2001). Each individual specimen caught was sexed, the total length (TL) and fork length (FL) were measured and rounded down to the nearest $\mathrm{mm}$ and the total weight (W) and eviscerated weight (We) recorded after rounding down to the nearest $\mathrm{mg}$. After evisceration, the saggitta otoliths were removed from each fish and stored dry. The gonads were removed, weighed (rounded down to the nearest $\mathrm{mg}$ ) and classified according to the maturity stages proposed by Gonçalves and Erzini (2000) for other Sparidae species. In addition, the date and location of capture along with other data such as hook size and bait for longline catches were recorded.

Linear regression was used to explore the relationships between the explanatory variable TL (in $\mathrm{cm}$ ) and the dependant variables FL (in $\mathrm{cm}$ ) without any data transformation and the natural logarithm transformed variables $\mathrm{W}$ and $\mathrm{We}$ (in g). Standard errors were calculated for all the parameters estimated, along with the coefficient of determination $\left(\mathrm{r}^{2}\right)$ of each regression. Linear regressions were carried out for males and females separately, and the analysis of covariance (ANCOVA) using TL as the covariate, was used to compare the two sexes.

\section{Age Determination and Verification}

Age was estimated by reading and interpreting the saggitta otoliths, the largest of the otoliths that are consequently most easily extracted and used in this type of study (Beckman and Wilson, 1995). Several techniques were tested preliminarily in order to assess the most adequate to read the growth bands of this species. Specifically, otoliths were observed after polishing, burning in a flame, baking in an oven for 3$6 \mathrm{~min}$ at $275^{\circ} \mathrm{C}$, sectioning transversely into $150-300$ $\mu \mathrm{m}$ thickness sections with an Isomet low speed cutting machine, immersing in glycerol (whole otoliths) for 1-5 min and finally watching them dried without any treatment. In addition, different types of lighting were tested (direct, diffuse and reflected) as well as filters of different colours (blue and yellow) and three types of backgrounds (white, black and transparent).

Of the above treatments, the cross sectioning of the otoliths and the immersion of whole otoliths in glycerol for 1 to $5 \mathrm{~min}$ gave the best results. Burning with a flame, baking in the oven and direct observation with no treatment gave poor results, while the rest of 
the treatments proved reasonable. On the basis of these preliminary trials and taking into consideration the simplicity (time required to process each otolith), it was decided to use the whole otoliths immersed in glycerol using a compound microscope and amplifications between 10 and $40 \mathrm{x}$, with a black background and under reflected light. The area selected for counting growth bands was the posterior region along the dorsal-ventral axis. Each otolith was observed by at least three experienced researchers and a valid age was only attributed if the three age estimations were in agreement. Those valid ages were then used to create an age-length key.

Age verification was accomplished by the marginal increment analysis technique. This technique is a simple and direct method of verifying the seasonality of the growth band deposition by measuring the marginal increment (Beamish and McFarlane, 1983; Jearld 1983). For this analysis, a minimum of 10 otoliths per month over a one-year period were selected randomly and analysed. The otoliths were observed under a compound microscope with an ocular micrometer, and the marginal increment (MIR) of each otolith was then calculated by:

$$
M I R=\frac{\left(R-R_{n}\right)}{\left(R_{n}-R_{n-1}\right)}
$$

where $R$ is the radius (the distance between the focus and the edge of the structure), $R n$ is the distance between the focus and the last annual band and $R n-1$ is the distance between the focus and the penultimate annual band. Monthly values of MIR were plotted to determine the annual pattern of band formation. Analysis of variance (ANOVA) was used to test for differences in the MIR values along the year and the multiple comparisons Student-Newman-Keuls (SNK) pairwise tests used to assess differences between pairs of months.

\section{Growth Modelling}

Growth was modelled according to different models, specifically the Von Bertalanffy Growth Function (VBGF), the Gompertz model and the logistic equation.

The VBGF is expressed as:

$$
L t=L_{\mathrm{inf}}\left(1-e^{-k(t-t 0)}\right)
$$

where $L t$ is the total length at age $t, L_{i n f}$ is the asymptotic length, $k$ is the growth coefficient and $t_{0}$ is the theoretical age when $L t=0$.

The Gompertz growth model is expressed as:

$$
L t=L_{\mathrm{inf}} e^{-e^{(-g(t-t 0))}}
$$

where $g$ is the Gompertz growth coefficient.
The logistic equation can be expressed as:

$$
L t=L_{\mathrm{inf}} /\left(1+\left(\left(L_{\mathrm{inf}}-L_{0}\right) / L_{0}\right)\left(e^{(-r t)}\right)\right)
$$

where $L_{0}$ is the theoretical length at birth and $r$ is the logistic growth coefficient.

Parameters and associated standard errors (SE) of all the models were estimated for all data with nonlinear least squares regression. Model comparison and selection were based on the small sample corrected form of the Akaike Information Criterion (AICC) (Shono, 2000), given by:

$$
A I C c=\frac{R S S}{n}+\frac{2 k(k+1)}{n-k-1}
$$

where RSS is the residual sum of squares, $n$ is the number of observations and $k$ is total number of estimated regression parameters. The smallest AIC $c$ value was the criterion used to select the "best" model $(A I C c, \min )$ and the differences between this "best" model and all others expressed as:

$$
\Delta i=A I C c, \mathrm{i}-A I C c, \min
$$

Reproductive Cycle

The reproductive cycle was studied by analysis of the gonads, with the sex and maturity stage of each specimen determined either visually directly with the naked eye or under the compound microscope. The maturity stages were attributed according to the stages proposed by Gonçalves and Erzini (2000) for other Sparidae species.

In order to identify the spawning period, the gonadosomatic index (GSI) was calculated and plotted over the year. For this index, gonads from juvenile specimens were excluded:

$$
\mathrm{GSI}=\frac{\text { Gonad weight }(\mathrm{g})}{\mathrm{We}(\mathrm{g})} \times 100
$$

Furthermore, the relative frequency of the different maturity stages along the year was plotted, with the objective of determining whether specific stages of maturity were occurring predominantly during specific seasons or periods of the year.

\section{Maturity}

The proportion of mature individuals by $1 \mathrm{~cm}$ TL size class was used to fit length based maturity ogives and to estimate the size at first maturity (TL at which $50 \%$ of the individuals are mature) (Gonçalves and Erzini, 2000). The logistic curve was fitted by non-linear least squares regression by: 


$$
P_{L i}=\frac{1}{1+e^{-b\left(L_{i}-L_{50}\right)}}
$$

where $P_{L i}$ is the proportion of mature individuals in the size class $L i, b$ the slope and $L_{50}$ the size at which $50 \%$ of individuals are mature.

The standard errors and the lower and upper limits of the $95 \%$ confidence intervals were calculated for each parameter estimated. The maturity ogives were fitted to males and females separately, and the maximum likelihood test (Kimura, 1980) used to compare the sexes. Age at first maturity was calculated by applying the growth equation to the previously estimated size at first maturity.

\section{REsUlts}

Sample characteristics

A total of 386 specimens were sampled, 124 (32.1\%) of them being males, $223(57.8 \%)$ females, 21 (5.4\%) immature and 18 (4.7\%) hermaphrodites. Males ranged in TL from 17.2 to $44.8 \mathrm{~cm}$ and females from 17.6 to $44.0 \mathrm{~cm}$. Immature specimens ranged from 12.0 to $19.6 \mathrm{~cm}$. The 18 hermaphrodite specimens caught ranged from 18.7 to $39.8 \mathrm{~cm}$ in TL.

Significant morphometric relations were established between the explanatory variable TL and the dependant variables FL, W and We. No significant differences between sexes were detected for the TLFL relationship (ANCOVA: $\mathrm{F}=0.02 ; \mathrm{p}$-value $=0.89$ ) so a relationship for both sexes combined was calculated. On the other hand, significant differences were detected between the sexes for the TL-W relation (ANCOVA: $\mathrm{F}=10.05$; $\mathrm{p}$-value $<0.01$ ) and between the TL-We relation (ANCOVA: $\mathrm{F}=13.11$; p-value $<0.01$ ) (Table 1).

\section{Age Determination and Verification}

A total of 378 otoliths were used for reading and interpretation of age, which included both sexes and immature specimens, covering all length classes present in the sample. The otoliths of P. erythrinus were relatively large and generally not difficult to read. Reading and interpretation of the annuli was successful in 355 out of the available 378 otoliths (93.9\%), with poor band discrimination or lack of concordance in the readings accounting for the remainder.

Estimated ages varied between 1 and 21 years, with $92 \%$ of readings between 1 and 12 years, as may be seen in the age-length key (Table 2). For males the oldest specimen identified was 21 years old, while the oldest female was 17 . Most age classes in this population showed no differences between the mean total length of males and females (Table 3), and therefore age length keys and growth models were estimated for both sexes combined.

Table 1. Linear regressions between TL and FL, W and We for Pagellus erythrinus. The total sample (n), type of data transformation, range of the explanatory variable $(\mathrm{cm})$, intersect (a) and slope (b) of the linear regression, with the respective standard errors (SE), are given. The coefficient of determination $\left(\mathrm{r}^{2}\right)$ of each regression is also shown.

\begin{tabular}{|c|c|c|c|c|c|c|c|c|c|}
\hline \multirow{2}{*}{ Relation } & \multirow{2}{*}{$\begin{array}{l}\text { Data } \\
\text { transf. }\end{array}$} & \multirow{2}{*}{ Sex } & \multicolumn{2}{|c|}{ Sample } & \multicolumn{5}{|c|}{ Parameters of the relationship } \\
\hline & & & $\mathrm{n}$ & Range & a & B & SE (a) & SE (b) & $r^{2}$ \\
\hline \multirow{3}{*}{$\mathrm{TL}-\mathrm{FL}$} & \multirow{3}{*}{ None } & Males & 120 & $17.2-44.8$ & -0.397 & 0.871 & 0.153 & 0.005 & 0.996 \\
\hline & & Females & 217 & $17.8-44.0$ & -0.412 & 0.870 & 0.112 & 0.004 & 0.996 \\
\hline & & All & 337 & $17.2-44.8$ & -0.442 & 0.872 & 0.086 & 0.003 & 0.996 \\
\hline \multirow{2}{*}{$\mathrm{TL}-\mathrm{W}$} & \multirow{2}{*}{ Nat $\log$} & Males & 122 & $17.2-44.8$ & -4.108 & 2.929 & 0.123 & 0.036 & 0.982 \\
\hline & & Females & 223 & $17.6-44.0$ & -4.071 & 2.910 & 0.089 & 0.027 & 0.982 \\
\hline \multirow{2}{*}{$\begin{array}{l}\text { TL- } \\
\mathrm{We}\end{array}$} & \multirow{2}{*}{ Nat $\log$} & Males & 122 & $17.2-44.8$ & -4.207 & 2.941 & 0.112 & 0.032 & 0.986 \\
\hline & & Females & 223 & $17.6-44.0$ & -4.153 & 2.913 & 0.095 & 0.029 & 0.979 \\
\hline
\end{tabular}


Table 2. Age-length key for Pagellus erythrinus in southern Portugal. n refers to sample size.

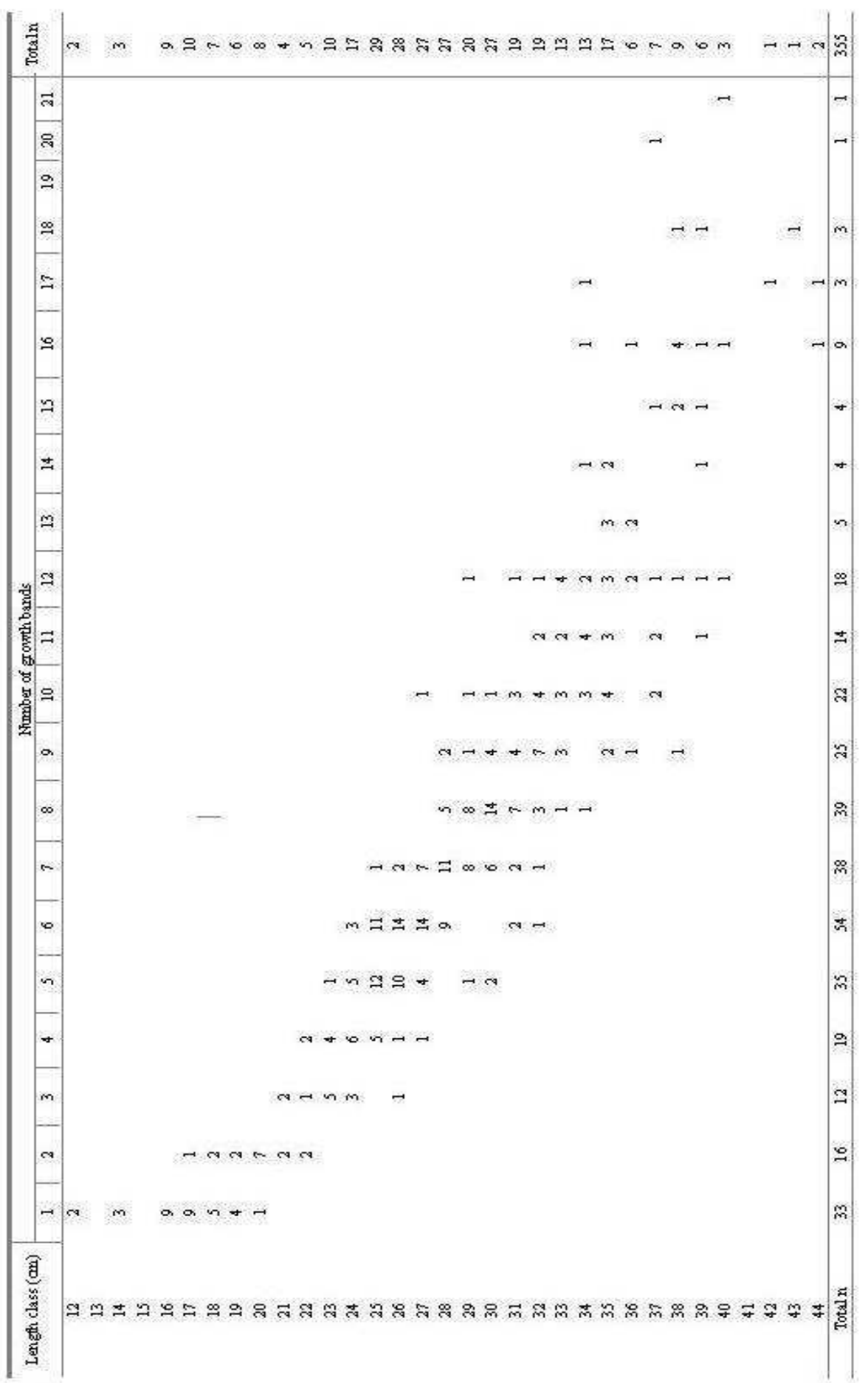


Table 3. Comparison of the mean total length (TL, $\mathrm{cm}$ ) of male and female Pagellus erythrinus for each age class. $\mathrm{n}=$ sample size and SD standard deviation. The Student's t-test statistical value and the decision regarding the null hypothesis $\left(\mathrm{H}_{0}\right.$ : no differences occur between mean length-at-age of males and females) are given.

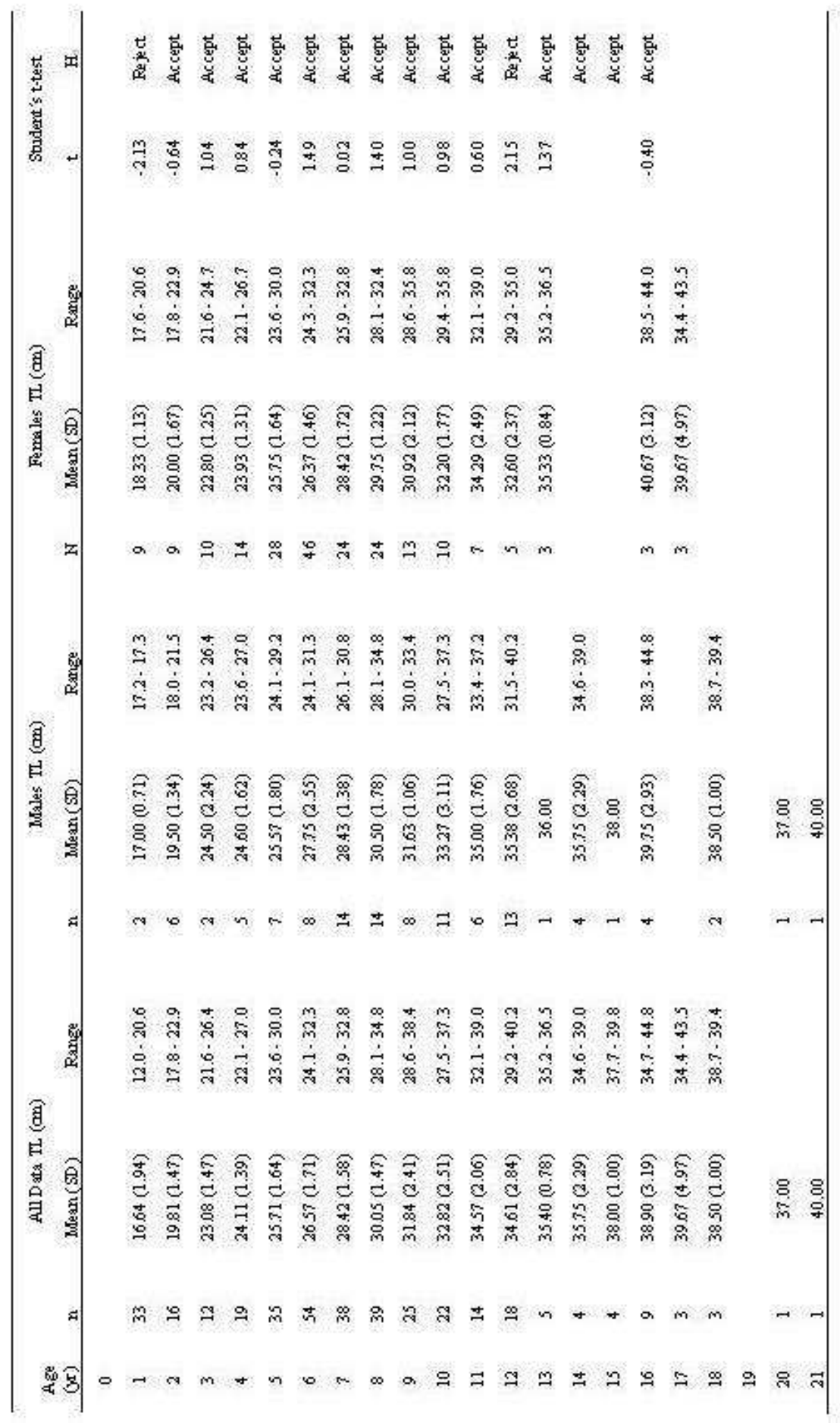


A clear pattern of band formation was observed with the marginal increment analysis. A sharp decrease of the marginal increment was observed during the spring, followed by a progressive increase during the summer and autumn with a peak observed during the colder months, from February to March (Fig. 1). Statistically significant differences were found between mean MIR values over the different months of the year (ANOVA: $\mathrm{F}=3.98$; $\mathrm{P}$ value $<0.001$ ). The Student-Newman-Keuls multiple comparison pairwise tests showed that there were statistically significant differences between the months with the highest MIR values (February-March) and those with the lowest MIR values (May to December).

\section{Growth Modelling}

The three different models used to estimate growth based on length-at-age data gave good fits and resulted in relatively similar curves (Fig. 2). The logistic curve produced the smaller asymptotic sizes, followed by the Gompertz model and finally the VBGF with the larger sizes. On the other hand, the logistic model produced the higher growth rates, followed by the Gompertz model and finally the VBGF with the lower values. All models fitted the data with high and similar values of $\mathrm{r}^{2}$ and $\Delta i<2$ for all cases. Therefore, all the models presented are adequate for modelling the growth of this species, although the VBGF produced slightly better results (Table 4).

Table 4. Comparison (with the respective standard error (SE) and limits of the $95 \% \mathrm{CI}$ ) of parameters estimated with the different growth models. In the growth curve comparison, $\mathrm{r}^{2}$ refers to the coefficient of determination, $A I C c$ to the small-sample corrected form of Akaike's Information Criterion and $\Delta i$ to Akaike's differences.

\begin{tabular}{|c|c|c|c|c|}
\hline & & VBGF & Gompertz & Logistic \\
\hline \multirow{4}{*}{ Asymptotic size (cm) } & Estimate & 47.140 & 43.389 & 41.495 \\
\hline & SE & 1.602 & 0.972 & 0.723 \\
\hline & Lower $95 \% \mathrm{CI}$ & 43.989 & 41.478 & 40.072 \\
\hline & Upper $95 \%$ CI & 50.291 & 45.300 & 42.918 \\
\hline \multirow{4}{*}{ Growth coefficient $\left(\right.$ year $^{-1}$ ) } & Estimate & 0.084 & 0.136 & 0.189 \\
\hline & $\mathrm{SE}$ & 0.007 & 0.008 & 0.009 \\
\hline & Lower $95 \% \mathrm{CI}$ & 0.069 & 0.120 & 0.171 \\
\hline & Upper 95\% CI & 0.098 & 0.151 & 0.206 \\
\hline \multirow{3}{*}{ Growth curve comparison } & $r^{2}$ & 0.9485 & 0.9482 & 0.9476 \\
\hline & $A I C c$ & 3.628 & 3.646 & 3.688 \\
\hline & $\Delta i$ & 0.000 & 0.019 & 0.060 \\
\hline
\end{tabular}

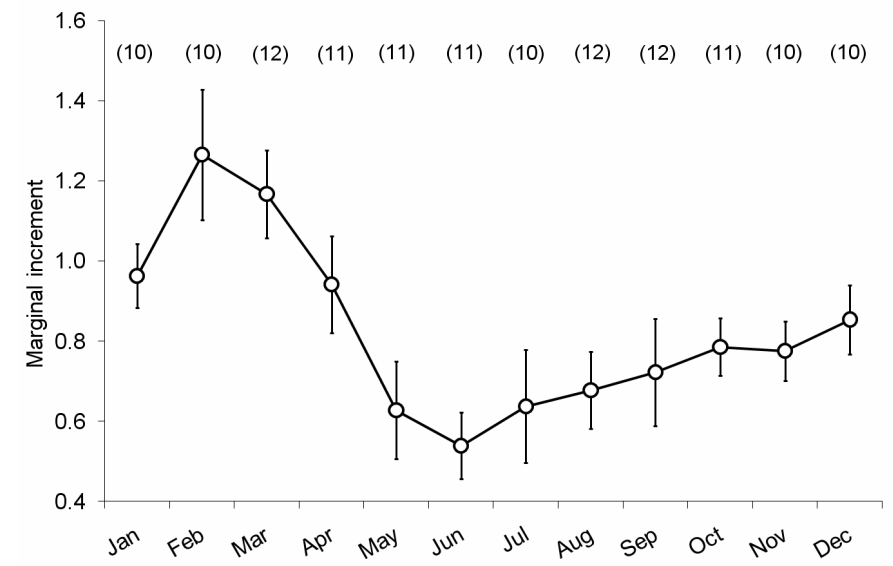

Fig. 1. Variation of the marginal increment over the year for Pagellus erythrinus. The error bars represent \pm standard deviation and the numbers between brackets the sample size (n). 


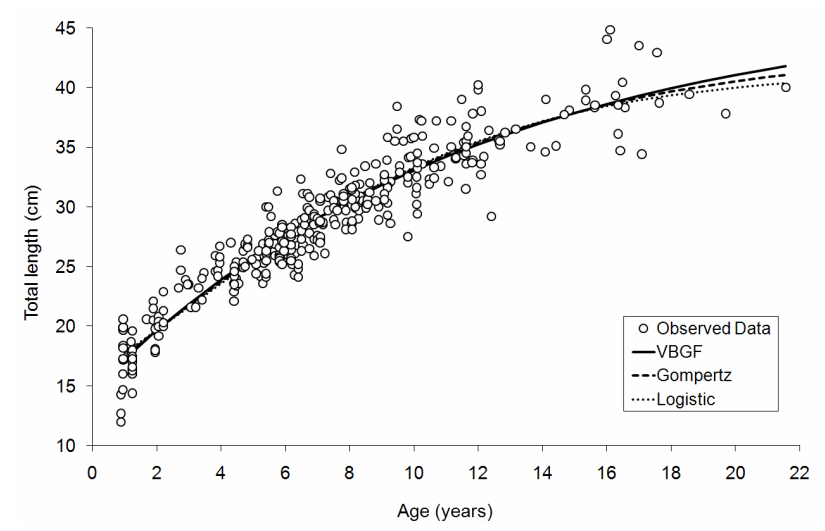

Fig. 2. Length at age data for Pagellus erythrinus, with the three fitted growth models.

\section{Reproductive Cycle}

The evolution of the mature reproductive stages throughout the year seems to evidence that the reproductive period for $P$. erythrinus starts in March and extends into July. Spawning males show a peak in June while females peak in March with most postspawning females occurring in July (Fig. 3).

The GSI variation throughout the year also shows a pattern with the same general spawning season (Fig. 4). Significant differences in the mean monthly GSI values were detected both for males

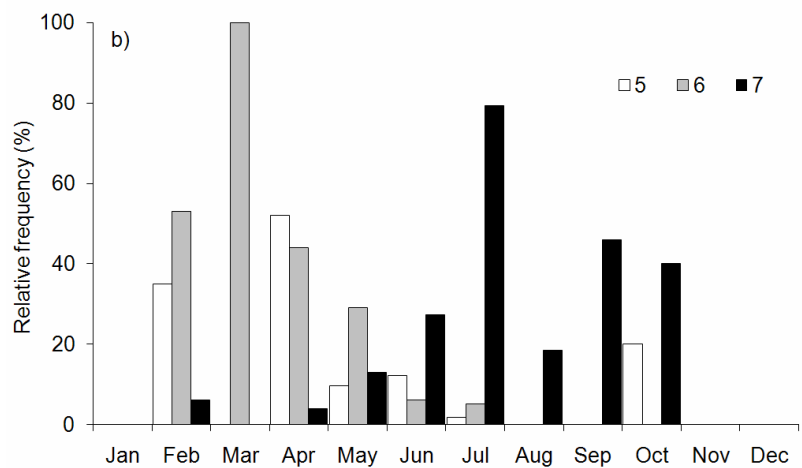

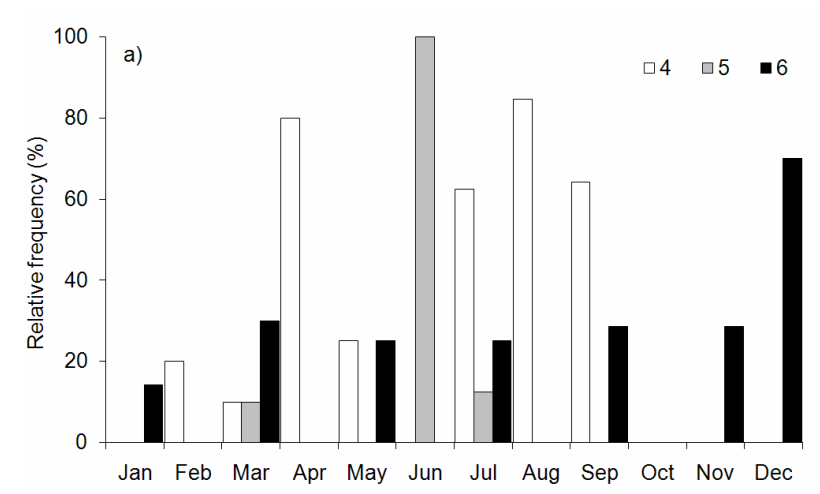

(ANOVA: $\mathrm{F}=14.80 ; \mathrm{p}$-value <0.01) and females (ANOVA: $\mathrm{F}=22.20 ; \mathrm{p}$-value $<0.01$ ). When the Student-Newman-Keuls multiple comparison pairwise tests were applied, it was possible to establish two distinct groups over the year among both males and females: among the males a group with higher GSI values occurred from March to September and another with lower values from October to February, while among the females a group with higher values occurred from April to July and another with lower values from August to March.
Fig. 3. Monthly evolution of the relative frequency for mature stages in males (a) and females (b) Pagellus erythrinus. In males, stage 4 represents developing, stage 5 emission and 6 post-emission and in females, stage 5 represents pre-spawning, 6 spawning and 7 postspawning. 


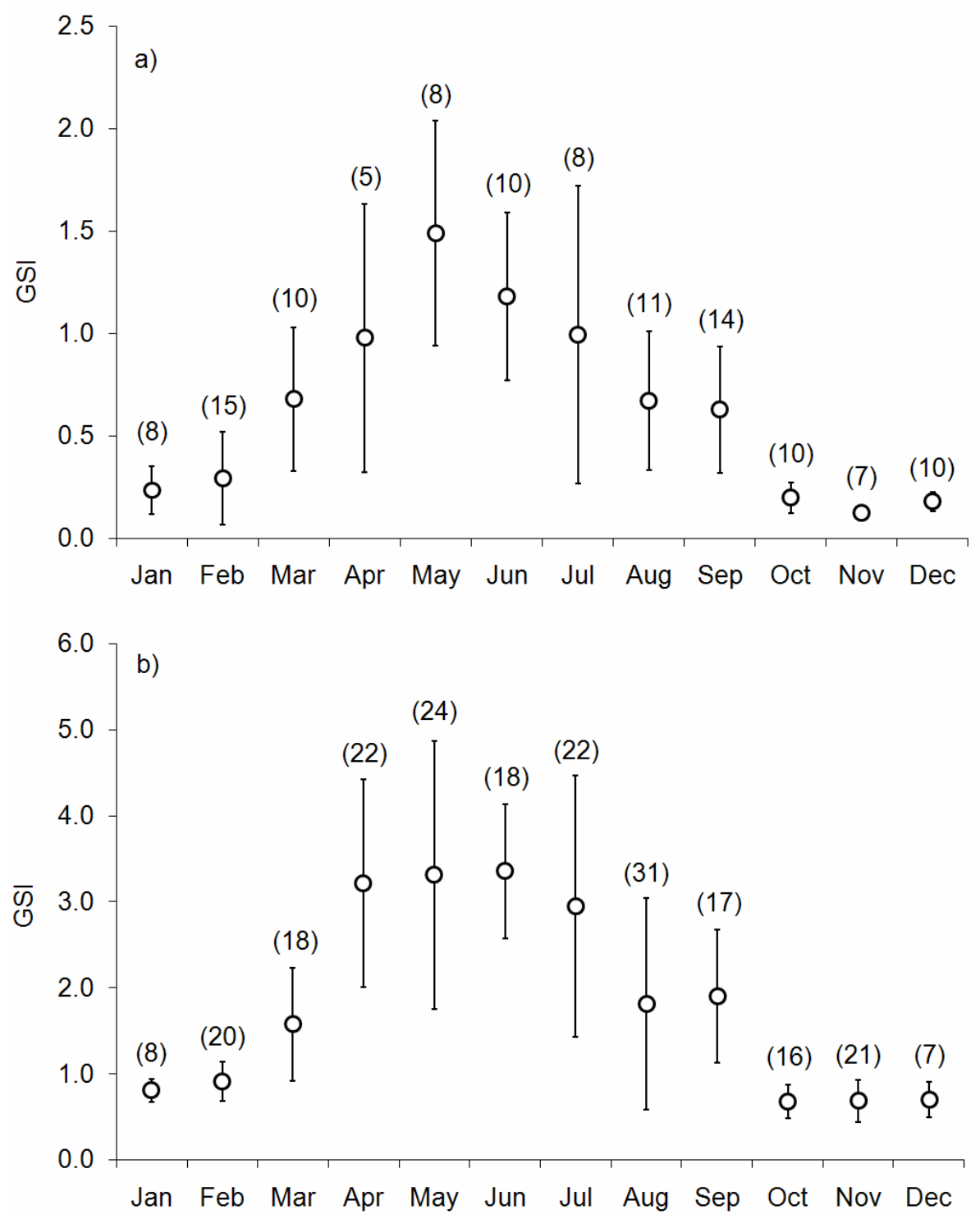

Fig. 4. Monthly evolution of the gonadosomatic index (GSI) for males (a) and females (b) of Pagellus erythrinus. The error bars represent \pm standard deviation and the numbers between brackets the sample size (n).

Maturity

The largest immature $P$. erythrinus had 19.6 $\mathrm{cm}$ TL and was 1.2 years of age. The smallest mature male had $17.2 \mathrm{~cm}$ TL and was 0.9 years old, while the smallest mature female had $17.6 \mathrm{~cm}$ TL and was also 0.9 years old. Size based maturity ogives produced good fits to the observed data, with high $\mathrm{r}^{2}$ values, namely 0.993 and 0.991 , respectively, for males and females. The length and age at maturity parameters showed that the males of this species mature at slightly larger sizes and greater ages than the females. Specifically, males mature at $17.58 \mathrm{~cm}$ TL and 1.15 years, while females mature at $17.29 \mathrm{~cm}$ TL and 1.04 years (Fig. 5). Even though relatively small, these differences were statistically significant, and therefore the parameters were estimated for the sexes separately (L ${ }_{50}$ Max. Likelihood: $\chi^{2}=53.89$; p-value $<0.05$ ). 


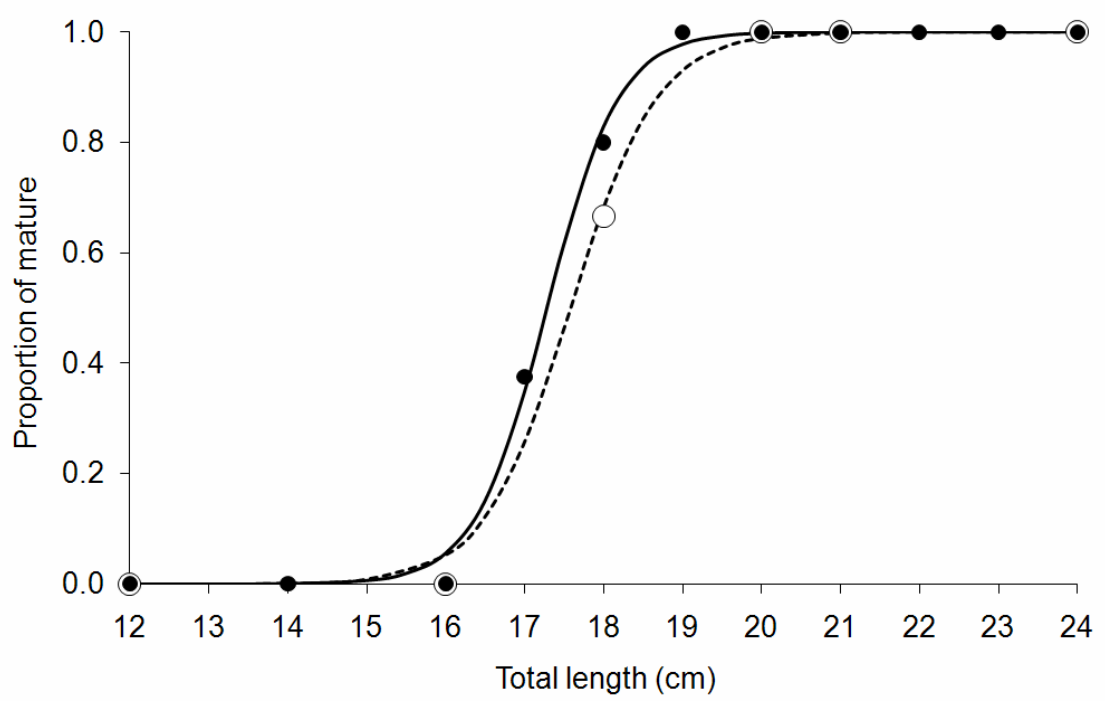

Fig. 5. Size-based maturity ogives for Pagellus erythrinus. Dark and white points represent the proportion of mature females and males in each size or age class, while the solid (females) and dotted (males) lines represent the corresponding fitted logistic curves.

\section{Discussion}

The southern coast of Portugal where this study was carried out is characterized by its nutrient rich shelf waters, due both to the upwelling that occurs during westerly wind events and to the trapping of coastal water in shallow areas where it warms up and is recharged with nutrients and phytoplankton under easterly wind events (Reul et al., 2006). This may be one of the reasons for the importance of this region for many coastal fish species, such as the common pandora on which this present study focuses.

The effort applied in this study to obtaining a complete range of lengths of $P$. erythrinus was successful only for the exploited part of the stock and it was not possible to obtain specimens smaller than 12 $\mathrm{cm}$ in TL. During this study, several beach seines were carried out inside the Ria Formosa, a coastal lagoon in southern Portugal, but even there no small-sized specimens were found. Other studies in other areas have ascertained that young-of-the-year common pandora live close to the shore, at depths down to 30 $\mathrm{m}$ (e.g. Ardizzone and Messina, 1983; Papaconstantinou et al., 1988; Mytilineou 1989), and therefore it would be reasonable to assume that smaller sized specimens might occur inside this shallow water coastal lagoon, but this was not the case. We may, therefore, conclude that young-of-the-year $P$. erythrinus in the southern Portuguese population might occur in shallow coastal waters, but not necessarily inside coastal lagoons, nor in estuaries or salt marshes (Veiga et al., 2006). This situation is the opposite to that found for other Sparidae species in the area, such as the common two-banded seabream, Diplodus vulgaris, or the black seabream, Spondyliosoma cantharus, whose immature specimens are found in large quantities inside these coastal lagoons and estuaries, usually associated with seagrass habitats (Ribeiro et al., 2006; Ribeiro et al., 2008).

The largest specimen in this study was a 44.8 cm TL male, while the oldest specimen aged was a 21 year old male measuring $40.0 \mathrm{~cm}$ TL. Few studies on $P$. erythrinus have presented specimens as large as those found in this study. In fact, only two studies have found specimens larger than $40 \mathrm{~cm}$, namely Mytilineou (1989) whose largest fish was $43 \mathrm{~cm}$ in FL (roughly $49.9 \mathrm{~cm}$ TL, converted) and Girardin and Quignard (1985) whose largest specimen measured $44.5 \mathrm{~cm}$ in FL (roughly $51.7 \mathrm{~cm} \mathrm{TL}$, converted).

Otoliths, the structures used for age estimation in the present study, are structures that consistently record the annual variations in bony fishes. The seasonal fluctuations in sea surface temperature and nutrient abundance observed along the Portuguese coast, mainly due to the occurrence of coastal upwelling during the summer and early autumn, and the predominance of general coastal convergence conditions during the winter, are the reasons most likely to explain these patterns in these structures. Many studies have used otoliths to successfully age other Sparidae species in the same geographical region (e.g. Gonçalves et al., 2003; Coelho et al., 2005; 
Monteiro et al., 2006). Abecasis et al. (2008) used this same dataset to compare otoliths and scales of several Sparidae species and concluded that in most cases otoliths would produce better results, even though in the specific case of $P$. erythrinus, scales might occasionally be easier to read.

The oldest fish in this sample is much older than any found in the literature. The oldest fish reported for this species in the literature is a 15 -year old female measuring $43.7 \mathrm{~cm}$ FL (roughly $50.7 \mathrm{~cm}$, converted) identified by Girardin and Quignard (1985). The big differences found between the work of Girardin and Quignard (1985) and the present study in terms of maximum ages estimated could be related to difficulties in interpreting the growth bands, particularly those of the older fish. In the present study, the age verification carried out with the marginal increment analysis technique is advantageous and provides some assurance that the growth bands are seasonal and deposited yearly. However, it should be noted that age verification with marginal increment analysis of individual age classes, as proposed by Beamish and McFarlane (1983), was not possible principally due to the relatively low sample size of many age classes. Further, it should be noted that a true age validation, i.e. the assurance that growth bands are equivalent to years, was not attained and for that purpose the use of other techniques such as tagging studies with oxytetracycline will be necessary in the future (Campana, 2001).

During this study, and for comparative purposes, three different models were used to estimate growth parameters. Even though all of them fitted the data well and could be used to describe the species' growth patterns, the von Bertalanffy growth function produced slightly better fits. The use of this model for this species is, therefore, advantageous, not only because it is the most adequate but also because it is the most widely used in fishery studies, its advantage being that its parameters are readily incorporated into stock assessment models. When compared with other values obtained by other authors for other populations, the growth parameters estimated during the present study $\left(L_{\text {inf }}=47.1 \mathrm{~cm} \mathrm{TL}\right.$ and $k=0.084$ year $\left.^{-1}\right)$ are amongst those with the highest $L_{\text {inf }}$ and the lowest $k$ values. In the Mediterranean, $L_{\text {inf }}$ values ranged from $30.0 \mathrm{~cm}$ in Cyprus (Livadas, 1989) to $48.2 \mathrm{~cm}$ in Greece (Mytilineou, 1989) while $k$ values ranged from 0.062 year $^{-1}$ in Greece (Mytilineou, 1989) to 0.337 year $^{-1}$ in the Gulf of Lion (Girardin and Quignard, 1985). In the only study previously carried out on an Atlantic population, specifically in the Canary Islands (Pajuelo and Lorenzo, 1998), again the values of $L_{i n f}$ were lower $(41.8 \mathrm{~cm})$ and those of $k$ higher $(0.205$ year $\left.^{-1}\right)$ than those found in the present study. These differences might be related specifically to the larger specimens present and caught in the southern Portuguese population.

The reproductive season of $P$. erythrinus in southern Portugal extends from March to July, with a peak during May-June. This is also the reproductive season reported by Livadas (1989) for the Mediterranean and Pajuelo and Lorenzo (1998) for the Canary Islands. This period coincides with the months when the otoliths start to deposit the opaque band and this seems to evidence that the pattern of deposition of growth bands is determined by the reproductive season and not only by environmental factors alone.

The occurrence of some hermaphrodites among larger fish must correspond to the change from female to male (protogynous hermaphroditism) which has already been observed by other authors (e.g. Buxton and Garratt, 1990). In this study this change occurs mainly at lengths between 34 and $39 \mathrm{~cm}$ TL, which corresponds to ages 11 to 16 . According to Buxton and Garratt (1990) this sexual inversion is an adaptation of this species to being a group spawner. With this spawning behaviour it is an advantage to have large testicles and release large amounts of sperm to guarantee that the largest possible number of eggs are fertilized; it is therefore a reproductive advantage that the largest fish should be predominantly males (Stockley et al., 1997).

The length at first maturity of $17.58 \mathrm{~cm}$ TL for males and $17.29 \mathrm{~cm}$ TL for females is higher than the minimum landing size (MLS) for common pandora in Portugal ( $15 \mathrm{~cm} \mathrm{TL})$, thus showing that the stock may be under-protected as regards catches of immature fish. It should, therefore, be recommended that the MLS in Portuguese waters be increased to $18 \mathrm{~cm}$, in order to ensure that at least $50 \%$ of the population has a chance to reproduce before being caught. The age at first maturity of 1.13 years for males and 1.04 years for females seems to evidence that part of the population might reproduce during the reproductive season (summer) on the year immediately after being born while other specimens might reproduce only in their second year. Other authors, including Mytilineou (1989), have reported that the common pandora matures during its second year.

In conclusion, this study suggests that the common pandora population in southern Portugal has a lower growth rate and larger maximum size than both the Canary Island or Mediterranean populations. In terms of reproductive seasonality, this population reproduces during the warmer months, mostly between May and June. The size at first maturity estimated is higher than the minimum landing size, so this mandatory value should be increased. The fact that large specimens were caught seems to suggest that this population at the date of sampling was not overexploited, but it should be noted that the data presented in this study was mostly collected between 
1995 and 1996, after the peak in catches recorded in the early 1990's but before the huge collapse in catches recorded after 2003. Further studies on this population should, therefore, be carried out, specifically to ascertain whether the population parameters have changed after a decade of intensive fishing exploitation.

\section{AcKNOWLEDGMents}

This work was funded in part by the Commission of the European Communities DG XIV (Ref. 98/082): Fisheries biology and assessment of demersal species (Sparidae) from the South of Portugal. Rui Coelho received a grant from FCT, the Portuguese Foundation for Science and Technology (Ref: BPD 40523 / 2007), co-funded by POCI 2010 and FSE, during part of this study.

\section{REFERENCES}

ABECASSIS, D; BENTES, L.; COELHO, R.; CORREIA, C.; LINO, P. G.; MONTEIRO, P.; GONÇALVES, J. M. S.; RIBEIRO, J.; ERZINI, K.. Ageing seabreams: A comparative study between scales and otoliths. Fish. Res., v. 89, n. 1, p. 37-48, 2008.

ANDALORO, F; GIARRITTA, S. P. Contribution to the knowledge of the age, growth and feeding of pandora, Pagellus erythrinus (L. 1758) in the Sicilian Channel. In: GARCIA, S.; CHARBONNIER, D. (eds.), Report of the Second Technical Consultation on Stock Assessment in the Central Mediterranean, 1985. p. 85-87. Mazara Del Vallo: General Fisheries Council for the Mediterranean.

ARDIZZONE, G. D.; MESSINA, A. Feeding habits of Pagellus erythrinus (L.) (Pisces, Sparidae) from the middle Tyrrhenian Sea. Rapp. P. V. Reun. CIESM, v. 28, p. 39-42, 1983.

BAUCHOT, M. L. Poissons osseux. In: FISCHER, W; BAUCHOT, M. L., SCHNEIDER, M. (eds.), Fiches FAO d'identification pour les besoins de la pêche. Méditerranée et mer Noire. Zone de pêche 37. 1987. p. 891-1421. Rome: FAO.

BAUCHOT, M. L.; HUREAU, J. C. Sparidae. In: WHITEHEAD, P. J. P.; BAUCHOT, M. L.; HUREAU, J. C.; NIELSEN, J.; TORTONESE, E. (eds.), Fishes of the north-eastern Atlantic and the Mediterranean. 1986. p. 883-907. Paris: UNESCO.

BEAMISH, R. J; MCFARLANE, G. A. The forgotten requirement of age validation in fisheries biology. Trans. Am. Fish. Soc., v. 112, n. 6, p. 735-743, 1983.

BECKMAN, D. W.; WILSON, C. A. Seasonal timing of opaque zone formation in fish otoliths. In: SECOR, D.H.; DEAN, J.M.; CAMPANA, S.E. (eds.), Recent Developments in Fish Otolith Research. 1995. p. 27-43. Columbia: University of South Carolina.

BUXTON, C. D.; GARRATT, P. A. Alternative reproductive styles in seabreams (Pisces: Sparidae). Environ. Biol. Fish., v. 28, n. 1-4, p. 113-124, 1990.

CAMPANA, S. E. Accuracy, precision and quality control in age determination, including a review of the use and abuse of age validation methods. J. Fish Biol., v. 59, n. 2, p. 197-242, 2001

COELHO, R.; BENTES, L.; CORREIA, C.; GONCALVES, J. M. S.; LINO, P. G.; MONTEIRO, P.; RIBEIRO, J.; ERZINI, K. Age, growth and reproduction of the axillary seabream, Pagellus acarne (Risso, 1827) from the south coast of Portugal. Thalassas, v. 21, n. 1, p. 79-84, 2005.

DGPA. Recursos da pesca. Lisboa: Direcção-Geral das Pescas e Aquicultura, 2006. $168 \mathrm{p}$

ERZINI, K., BENTES, L.; COELHO, R., CORREIA, C., LINO, P. G.; MONTEIRO, P.; RIBEIRO, J.; GONÇALVES, J. M. S. Fisheries biology and assessment of demersal species (Sparidae) from the South of Portugal. 2001. 263 p. Final Report Universidade do Algarve.

ERZINI, K.; GONCALVES, J. M. S.; BENTES, L.; LINO, P. G.; CRUZ, J. Species and size selectivity in a Portuguese multispecies artisanal long-line fishery. ICES J. Mar. Sci., v. 53, n. 5, p. 811-819, 1996.

ERZINI, K.; GONÇALVES, J. M. S.; BENTES, L.; LINO, P. G.; RIBEIRO, J. Species and size selectivity in a 'red' sea bream longline 'metier' in the Algarve (southern Portugal). Aquat. Living Resour., v. 11, n. 1, p. 1-11, 1998.

GIRARDIN, M.; QUIGNARD, J. P. Growth of Pagellus erythrinus in the Gulf of Lions. Cybium, v. 9, n. 4, p. 359-374, 1985.

GOMES, M. C.; SERRÃO, E.; BORGES, M. F. Spatial patterns of groundfish assemblages on the continental shelf of Portugal. ICES J. Mar. Sci., v. 58, n. 3, p. 633647, 2001.

GONÇALVES, J. M. S.; BENTES, L.; COELHO, R.; CORREIA, C.; LINO, P.G.; MONTEIRO, P.; RIBEIRO, J.; ERZINI, K. Age and growth, maturity, mortality and yield-per-recruit for two banded bream (Diplodus vulgaris Geoffr.) from the south coast of Portugal. Fish. Res., v. 62, n. 3, p. 349-359, 2003.

GONÇALVES, J. M. S.; BENTES, L.; LINO, P. G.; RIBEIRO, J.; CANÁRIO, A. V. M.; ERZINI, K. Weight-length relationships for the most important species of the small-scale demersal fisheries of south and south-west coast of Portugal. Fish. Res., v. 30, n. 3, p. 253-256, 1997.

GONÇALVES, J. M. S.; ERZINI, K. The reproductive biology of the two-banded sea bream (Diplodus vulgaris) from the southwest coast of Portugal. J. Appl. Ichthyol., v. 16, n. 3, p. 110-116, 2000.

JEARLD, A. Age determination. In: L. A. Nielsen and D.L. Johnson (eds.), Fisheries Techniques. 1983. p. 301-324. Bethesda: American Fisheries Society.

KIMURA, D. K. Likelihood methods for the von Bertalanffy growth curve. Fish. Bull., v. 77, n. 4, p. 765-776, 1980.

KLAOUDATOS, S. D.; IAKOVOPOULOS, G.; KLAOUDATOS, D. S. Pagellus erythrinus (common pandora): a promising candidate species for enlarging the diversity of aquaculture production. Aquacult. Int., v. 12, n. 3, p. 299-320, 2004.

LIVADAS, R. J. A study of the biology and population dynamics of pandora (Pagellus erythrinus L., 1758), family Sparidae, in the seas of Cyprus. In: SAVINI, M.; CADDY, J.F. (eds.), Report of the Second Technical Consultation on Stock Assessment in the Eastern Mediterranean. 1989. p. 58-76. Athens: General Fisheries Council for the Mediterranean. 
MONTEIRO, P.; BENTES, L.; COELHO, R.; CORREIA C.; GONÇALVES, J. M. S.; LINO, P.G.; RIBEIRO, J.; ERZINI, K. Age and growth, mortality, reproduction and relative yield per recruit of the bogue, Boops boops Linné, 1758 (Sparidae), from the Algarve (south of Portugal) longline fishery. J. Appl. Ichthyol., v. 22, n. 5, p. 345-352, 2006.

MYTILINEOU, C. Biological data on the pandora, Pagellus erythrinus, of the eastern coasts of central Greece. In: SAVINI, M.; CADDY, J.F. (eds.), Report of the Second Technical Consultation on Stock Assessment in the Eastern Mediterranean. 1989. p. 77-82. Athens: General Fisheries Council for the Mediterranean, Athens.

PAJUELO, J. G.; LORENZO, J. M. Population biology of the common pandora Pagellus erythrinus (Pisces: Sparidae) off the Canary Islands. Fish. Res., v. 36, n. 2-3, p. 75-86, 1998.

PAPACONSTANTINOU, C.; MYTILINEOU, C.; PANOS, T. Aspects of the life history and fishery of red pandora, Pagellus erythrinus (Sparidae) off western Greece. Cybium, v. 12, n. 4, p. 267-280, 1988.

REINER, F. Catálogo dos peixes do arquipélago de Cabo Verde. Lisboa: IPIMAR. 1996. 339 p.

REUL, A.; MUNÕZ, M.; CRIADO-ALDEANUEVA, F.; RODRÍGUEZ, V. Spatial distribution of phytoplankton $<13 \mu \mathrm{m}$ in the Gulf of Cádiz in relation to water masses and circulation pattern under westerly and easterly wind regimes. Deep-Sea Res. Part II-Top. Stud. Oceanogr., v. 53, n. 11-13, p. 1294-1313, 2006.

RIBEIRO, J.; BENTES, L.; COELHO, R., GONÇALVES, J.M.S.; LINO, P.G.; MONTEIRO, P.; ERZINI，K Seasonal, tidal and diurnal changes in fish assemblages in the Ria Formosa lagoon (Portugal). Est. Coast. Shelf. Sci., v. 67, n. 3, p. 461-474, 2006.

RIBEIRO, J.; MONTEIRO, C. C.; MONTEIRO, P.; BENTES, L.; COELHO, R.; GONÇALVES, J. M. S.; LINO, P. G.; ERZINI, K. Long-term changes in fish communities of the Ria Formosa coastal lagoon (southern Portugal) based on two studies made 20 years apart. Est. Coast. Shelf. Sci., v. 76, n. 1, p. 57-68, 2008.

SANCHES, J.G. Catálogo dos principais peixes marinhos da República de Guiné-Bissau. Lisboa: IPIMAR. 1991. 429 p.
SANTOS, M. N.; MONTEIRO, C. C.; ERZINI, K. Aspects of the biology and gillnet selectivity of the axillary seabream (Pagellus acarne, Risso) and common pandora (Pagellus erythrinus, Linnaeus) from the Algarve (south Portugal). Fish. Res., v. 23, n. 3-4, p. 223-236, 1995.

SHONO, H. Efficiency of the finite correction of Akaike's information criteria. Fish. Sci., v. 66, n. 3, p. 608-610, 2000

SOMARAKIS, S.; MACHIAS, A. Age, growth and bathymetric distribution of red pandora (Pagellus erythrinus) on the Cretan shelf (eastern Mediterranean). J. Mar. Biol. Ass. U.K., v. 82, n. 1, p. 149-160, 2002.

STERGIOU, K. I.; MOUTOPOULOS, D. K.; SORIGUER, M. C.; PUENTE, E.; LINO, P. G.; ZABALA, C.; MONTEIRO, P.; ERRAZKIN, L.A.; ERZINI, E. Trammel net catch species composition, catch rates and métiers in southern European waters: A multivariate approach. Fish. Res., v. 79, n. 1-2, p. 170-182, 2006.

STOCKLEY, P.; GAGE, M. J. G.; PARKER, G.A.; MOLLER, A.P. Sperm competition in fishes: the evolution of testis size and ejaculate characteristics. Am. Nat., v. 149, n. 5, p. 933-954, 1997.

VEIGA, P.; VIEIRA, L.; BEXIGA, C.; SÁ, R.; ERZINI, K. Structure and temporal variations of fish assemblages of the Castro Marim salt marsh, southern Portugal. Est. Coast. Shelf. Sci., v. 70, n. 1-2, p. 27-38, 2006.

(Manuscript received 13 November 2009; revised 25 March 2010; accepted 06 May 2010) 